\title{
EFFECT OF BUFFALO AND COW SKIM MILK FLOURIDIZATION ON 1-SOME PHYSICO-CHEMICAL PROPERTIES
}

( Received: 3.4. 2008 )

\author{
By \\ I. H. I. Abd El-Ghany \\ Dairy Science and Technology Department, Faculty of Agriculture,Cairo University, Giza, \\ Egypt
}

\begin{abstract}
The effect of added sodium fluoride (NaF, 5-20 ppm. Fo) on some physico-chemical properties of buffalo's and cow's skim milk was investigated. Adding NaF (5-20 p.p.m. Fo) had no significant effect $(\mathrm{P} \geq 0.05)$ on the $\mathrm{pH}$. The level of soluble calcium and the electrical conductivity $(\mathrm{EC})$ were significantly decreased $(\mathrm{P} \leq 0.05)$ by adding $\mathrm{NaF}$ to buffalo's skim milk, but apposite trend was observed with cow's skim milk. Added NaF increased the ionic fluoride, and this effect increased with increasing the concentration of $\mathrm{NaF}$. The optical properties at 280 and $260 \mathrm{~nm}$ of both milks contained (5-20 p.p.m. Fo) were higher than those of the control samples. Cow's skim milk containing 15-20 p.p.m. Fo was higher ethanol stability at $85-90 \%$ than that of buffalo's samples. Fluoridated buffalo's skim milk (10-20 p.p.m. F.) was more stable towards 5 and $7.5 \mathrm{mmol} / \mathrm{L} \mathrm{Ca}^{2+}$ compared with the control, but the corresponding cow's treatments were not influenced. Also, all fluoridated milk samples were heat stable. The rennet clotting time, firmness and synersis of buffalo's skim milk were higher significantly $(\mathrm{P} \leq 0.05)$ with adding 20 p.p.m. F than those of cows.
\end{abstract}

Key words: buffalo's skim milk, electrical conductivity, firmness, Synersis heat stable, NaF, optical properties, Physico-chemical properties, Rennet clotting time.

\section{INTRODUCTION}

The only proved function of fluorine as a trace element in human nutrition is to improve the resistance of teeth to decay, apparently by improving the structure of teeth. Because of only important source of fluorine are tea and sea fish, unless the water contains 1 p.p.m. or more, if infants and young children often fail to obtain the benefits of fluorine when their teeth are being formed (Rugg-Gunn, 1993, Villa et al., 1998 and El-Gabry and Darwish, 2003). Therefore, the fluoridation of water in order to decrease incidence of dental caries (American Academy of Pediatrics, 1979, 1986, Al-Khateeb et al., 1991 and Levy et al., 1995).

Milk is the natural food for infants and children. The use of milk for fluoridation of children diet would ensure that infants and young children obtained the necessary amount of fluoride but also a useful supply of calcium, phosphorus, vitamin $\mathrm{D}$, good quality protein and other important nutrients (Davis, 1975 a,b, Villa et al., 1989 and Bian et al., 1995). However, the fluoride content of milk may vary according to the fluoride content of animal feed, species of milk, drinking water, the surrounding environment, processing of milk and milk products and supplementation or fortification of milk with fluoride (Junkkarinen and Kreula, 1976, Shehata et al., 1985, Garrec and Plebin, 1986 and Wheeler et al., 1988 a,b). Flouride in milk exists in two chemical forms: as ionic or free fluoride and bound fluoride. Ionic fluoride refers to fluoride ion still in solution, while bound fluoride refers to the fluoride that has a complex with other elements or compounds (calcium or protein for example)

Fluoridation of milk is cheaper and easier than fluoridation of water and there is no evidence of any adverse effect on the processing quality of the milk. Also, milk 
fluoridation was effective in improving the dental health of children and that the protective effect was increasing by exposing children to fluoridated milk at an earlier age (Davis, 1979, Marino, 1995 and Banoczy, 1997, Bian et al., 2004).

Sodium fluoride $(\mathrm{NaF})$ is by far commonly used for large scale production of fluoridation milk. Fluoridated milk is produced with different concentration of fluoride but a typical value may be 5 ppm F. (American Academy of Pediatrics, 1979 and 1986). Previous studies had investigated the supplemented milk with $\mathrm{NaF}$ and processing effect on the chemical nature, stability and milk protein interactions of fluoridated milk and milk products (Beddows, 1982, Beddows and Blake, 1974, 1982, Wheeler et al., 1988a and Wieczorek et al., 1992). However, so far no work has been conducted on the physico-chemical properties of fluoridated buffalo's milk. Therefore, this study was planned to investigate the influence of added $\mathrm{F}^{-}$as $\mathrm{NaF}$ at different concentration (5-20 ppm.) on some physico-chemical properties of fluoridated buffalo's skim milk compared with those of cow's skim milk.

\subsection{Materials}

\section{MATERIALS AND METHODS}

\subsubsection{Milk samples}

Fresh raw bulk of both buffalo's and cow's milk obtained from the herds of the Fac. Agric., Cairo Univ. The milk samples were separated twice using a cream separator. The residual fat was removed by centrifugation at $3000 \mathrm{rpm}$ for $15 \mathrm{~min}$. at $5^{\circ} \mathrm{C}$.

2.1.2 Sodium fluoride solution (NaF) Analytical grade sodium fluoride (Sigma Chemical Co.) was dried and $2.210 \mathrm{~g}$ weighed, dissolved in distilled-deionized water and made to $1 \mathrm{~L}(1000 \mathrm{mg}$ Fo /L).Fluoride standards: Appropriate dilutions of prepared $\mathrm{NaF}$ solution were used to give standard solutions in distilleddeionized water of 30 to $0.01 \mathrm{mg} \mathrm{F} / \mathrm{L}$.

\subsubsection{Preparation of fluoridated milk}

Buffalo's and cow's skim milk samples of known added fluoride concentrations (5, 10, 15 and 20 p.p.m Fo) were prepared by the addition of appropriate volumes of aqueous sodium fluoride (1000 ppm Fo) to known volumes of milk with stirring.
Samples were left standing for one hour to equilibrate at room temperature $25^{\circ} \mathrm{C}$. The control samples were prepared without adding $\mathrm{NaF}$.

\subsection{Methods of analysis}

The fluoridated and non-fluoridated milk samples were analysed for $\mathrm{pH}$ and titratable acidity. Electrical conductivity (EC) was measured by digital conductivity meter (Henkel Canada Ltd), automatic correction of the conductivity measured to the reference temperature $\left(25^{\circ} \mathrm{C}\right)$ and reported as $\mathrm{mil} / \mathrm{mhos} / \mathrm{cm}(\mu \mathrm{s} / \mathrm{cm})$. Soluble calcium was determined by using the EDTA method as described by Natailianas and Whiteny (1964). For the determination of ionic fluoride, the samples after casein precipitation were adjusted to $\mathrm{pH} 5.5$ (Wheeler et al., 1988b), Spadns method was used according to the standard method for the examination of water and waste water (1989).

\subsubsection{Optical properties measurements}

The method of Nakai and Le (1970) was followed. Five $\mathrm{ml}$ of $97 \%$ acetic acid were added to $0.05 \mathrm{ml}$ of fluoridated milk samples in test tube with ground-glass stopper and shaked to ensure complete solubility. The absorbance of the diluted solutions was measured at $260 \mathrm{~nm}$ and 280 $\mathrm{nm}$ that indicate aromatic amino acids using a Unicam 8625 UV/VIS spectrophotometer (Ati Laicam, England)

\subsubsection{Determination of milk stabilities \\ 2.2.2.1. Ethanol stability}

Equal volumes of milk samples and aqueous ethanol solutions were mixed in test tubes and examined for immediate precipitation. The minimum concentration (v/v \%) of added ethanol solution which caused the immediate formation of visible particulate matter was defined as the ethanol stability (Horne and Parker, 1980).

\subsubsection{2. $\mathrm{Ca}^{2+}$ stability}

Equal volumes of milk samples and $\mathrm{CaCl}_{2}$ solutions were mixed with mechanical stirring, to give a final $\mathrm{Ca}^{2+}$ concentration of 30 to $5 \mathrm{mM} / \mathrm{L}$ and examined for clots or fine particular material.

\subsubsection{Heat stability}

The heat stability of fluoridated milk (5 to $20 \mathrm{ppm} \mathrm{F}$ ) was determined at $125^{\circ} \mathrm{C}$ for $30 \mathrm{~min}$. in thermostatically controlled oil bath for clots or fine particular material. 


\subsubsection{Determination of coagulation properties}

\subsubsection{Determination of rennet clotting} time (RCT)

Twenty five $\mathrm{ml}$ of the fluoridated milk samples were coagulated at $35^{\circ} \mathrm{C}$ using Chymax (Pfizer Inc., Milwaukee, WI, U.S.A) at enzyme/substrate (E/S) of 0.008 and RCT were determined according to Berridge (1952).

\subsubsection{Determination of curd firmness}

The firmness of the rennet coagulum expressed in newtons $(\mathrm{N})$ at $10 \mathrm{~mm}$, was measured using Accu Forsc $®$ II Ametek texture analyzer (Manfield\&Green Division, U.S.A.) as described by Tamime et al., (1989).

\subsubsection{Determination of curd Synersis}

The volume of whey expelled from the rennet curd in $60 \mathrm{~min}$ after cutting at $35^{\circ} \mathrm{C}$ was measured according to Marshall (1982).

\subsubsection{Statistical analysis}

The fluoridated and non-fluoridated milk samples were triplicated, and duplicate were performed on each replicate. Analysis of variance was performed by the SAS general liner methods (SAS, 2000) and differences were considered significant at $\mathrm{P}$ $\leq 0.05$.

\section{RESULTS AND DISCUSSION}

\subsection{Some physico-chemical properties}

The results obtained in Table (1) show that the addition of 5-20 ppm $\mathrm{F}$ (as NaF ) had no significant effect on the $\mathrm{pH}$ of buffalo's and cow's skim milk samples. These results are in agreement with (Beddows, 1982) who reported that addition of up to $1000 \mathrm{ppm} \mathrm{F}$ (as $\mathrm{NaF}$ ) to skim milk did not significantly affect $\mathrm{pH}$ and did not result in precipitation even after standing for $24 \mathrm{~h}$ at $20^{\circ} \mathrm{C}$.

The concentration of soluble calcium in buffalo's skim milk was significantly decreased and the opposite trend was observed in cow's skim milk with adding 15-20 ppm Fo (Table 1). The change in the level of soluble calcium by adding $\mathrm{NaF}$ may be attributed to dissociation of ionized $\mathrm{NaF}$ when dissolved in milk, thus $\mathrm{NaF} \leftrightarrow \mathrm{Na}^{+}+$ $\mathrm{Fo}$ and the $\mathrm{Ca}^{++}$would be found and precipitates as $\mathrm{CaF}_{2}$ or added fluoride forms a reversible ionic complex with milk protein. However, the fact that an increase in ionic strength (i.e., on adding $\mathrm{NaF}$ at higher concentration) leads to a reduction in the ion activity coefficient of calcium phosphate which causes an increase in solubility and dissociation of calcium phosphate or exchange with $\mathrm{Ca}^{++}$attached to micelles resulting an increase in soluble calcium (Davis, 1975a, Beddows and Blake 1982 and Wieczorek et al., 1992).

The analysis of variance of soluble calcium proved that there were significant differences $(\mathrm{P} \leq 0.05)$ between the two species of milk.

Table (1) also, shows that adding up to 20 ppm $\mathrm{F}$ (as $\mathrm{NaF}$ ) progressively increased the ionic Fo content from 1.95 and 1.85 to 11.95 and 9.95 ppm for buffalo's and cow's skim milk respectively. These obtained different results may be due to difference in ionic strength of $\mathrm{NaF}$ added and differences in the composition of casein micelles between buffalo's and cow's milk, In this respect previous published studies indicated about $85 \%$ of $\mathrm{NaF}$ added to skim milk remained in solution and release in ionic form after precipitation of the protein and value of ionic fluoride were $46-61 \%$ of the total fluoride (Wheeler et al., 1988b).

As regards electrical conductivity (EC) of milk that is due mainly to its salt fraction and the protein contribution is of minor importance whereas fat and lactose can not conduct current. On the other hand, the distribution of salt fractions between soluble and colloidial phase has an important effect on the overall milk conductivity (Mabrook and Petty, 2003).

Data in Table (1) illustrate that the control sample of cow's skim milk had higher EC than that of buffalo's sample. These results are in good agreement with those reported earlier (El-Shibiny and Abd El-Salam, 1973, El-Shabrawy and Haggag, 1980, Therdthai and Zhou, 2001). Adding up to $20 \mathrm{ppm}$ Fo progressively reduced and increased the EC of buffalo's and cow's samples, respectively. $\mathrm{NaF}$ induced reduction in the EC may be attributed to increase the ionic strength, interfered with mineral fractions of milk therefore decreased EC. However, the increase of EC through the addition of $\mathrm{NaF}$ may be aresult of increase concentration of monovalent cation or increase soluble calcium (Sharma and Sindhu, 2001). Statistical analysis (Table 1). revealed a significant effect 
Table (1): Influence of added NaF (5-20 p.p.m. F ) on some physico-chemical properties of buffalo's and cow's skim milk.

\begin{tabular}{|c|c|c|c|c|c|c|c|c|c|c|c|c|}
\hline \multirow{2}{*}{$\begin{array}{l}\mathrm{F} \text { as } \\
\mathrm{NaF} \\
\text { (p.p.m.) }\end{array}$} & \multicolumn{3}{|c|}{ pH } & \multicolumn{3}{|c|}{ Soluble calcium mg/100ml } & \multicolumn{3}{|c|}{ Ionic F p.p.m. } & \multicolumn{3}{|c|}{$\mathrm{EC}(\mu \mathrm{s} / \mathrm{cm})$} \\
\hline & BSM & CSM & Mean & BSM & CSM & Mean & BSM & CSM & Mean & BSM & CSM & Mean \\
\hline Control & 6.60 & 6.700 & 6.680 & $65.235^{\mathrm{A}}$ & $46.240^{\mathrm{D}}$ & $55.738^{\mathrm{c}}$ & $1.950^{\mathrm{F}}$ & $1.850^{\mathrm{F}}$ & $1.900^{\mathrm{f}}$ & $4.815^{\mathrm{D}}$ & $5.335^{\mathrm{C}}$ & $5.075^{\mathrm{c}}$ \\
\hline 5 & 6.665 & 6.740 & 6.703 & $66.235^{\mathrm{A}}$ & $45.880^{\mathrm{D}}$ & $55.558^{\mathrm{c}}$ & $\begin{array}{l}4.000^{\mathrm{E}} \\
(80.00)\end{array}$ & $\begin{array}{l}2.050^{\mathrm{F}} \\
(41.00)\end{array}$ & $3.025^{\mathrm{d}}$ & $4.745^{\mathrm{E}}$ & $5.615^{\text {B }}$ & $5.180^{\mathrm{a}}$ \\
\hline 10 & 6.675 & 6.735 & 6.705 & $66.315^{\mathrm{A}}$ & $45.880^{\mathrm{D}}$ & $56.089^{\mathrm{bc}}$ & $\begin{array}{l}8.550^{\mathrm{C}} \\
(85.5)\end{array}$ & $\begin{array}{c}7.250^{\mathrm{D}} \\
(7.25)\end{array}$ & $7.900^{\mathrm{c}}$ & $4.670^{\mathrm{F}}$ & $5.610^{\mathrm{B}}$ & $5.140^{\mathrm{b}}$ \\
\hline 15 & 6.655 & 6.730 & 6.693 & $63.090^{\mathrm{B}}$ & $50.905^{\mathrm{C}}$ & $56.998^{\mathrm{ab}}$ & $\begin{array}{l}8.550^{\mathrm{C}} \\
(57.00)\end{array}$ & $\begin{array}{l}9.000^{\mathrm{C}} \\
(60.00)\end{array}$ & $8.775^{b}$ & $4.665^{\mathrm{E}}$ & $5.640^{\mathrm{B}}$ & $5.153^{b}$ \\
\hline 20 & 6.675 & 6.740 & 6.707 & $63.096^{\mathrm{B}}$ & $51.260^{\mathrm{C}}$ & $57.175^{\mathrm{a}}$ & $\begin{array}{c}11.950^{\mathrm{A}} \\
(60.00)\end{array}$ & $\begin{array}{l}9.950^{\mathrm{B}} \\
(50.00)\end{array}$ & $10.950^{\mathrm{a}}$ & $4.335^{\mathrm{G}}$ & $5.680^{\mathrm{A}}$ & $5.008^{\mathrm{d}}$ \\
\hline Mean & $6.666^{\mathrm{b}}$ & $6.729^{\mathrm{a}}$ & & $64.590^{\mathrm{a}}$ & $48.030^{\mathrm{b}}$ & & $7.00^{\mathrm{a}}$ & $6.020^{\mathrm{b}}$ & & $4.646^{\mathrm{b}}$ & $5.576^{\mathrm{a}}$ & \\
\hline S.E & 0.0040 & 0.0094 & & & 0.4585 & & & & & 0.0555 & 0.0410 & \\
\hline
\end{tabular}

BSM= Buffalo's skim milk.

EC=Electrical conductivity.

CSM= Cow's skim milk.

Different superscripts $(A, B, C, a, b, c, \ldots)$ at the same column are significantly different $(\mathrm{P} \leq 0.05)$.

Figures in parenthesis indicate proportion $\%$ of added fluoride in ionic form.

S.E $=$ Standard Error. 
$(\mathrm{P} \leq 0.05)$ of adding $\mathrm{NaF}$ on the $\mathrm{EC}$ of both milk samples.

\subsection{Optical properties}

Data in Table (2) show that the optical properties (optical density at 280 and $260 \mathrm{~nm}$ ) of buffalo's and cow's skim milk containing 5-20 $\mathrm{ppm} \mathrm{F}^{-}$(as NF) were higher significantly than those of the control samples. The cow's samples had higher optical properties values than the corresponding values of buffalo's samples. The effect of $\mathrm{NaF}$ on optical properties changes may be attributed to interactions between $\mathrm{NaF}$ and tyrosine, histidine, phenylalaline and tryptophan residues.

Results in Table (3) indicate that cow's samples of skim milk containing 1520 ppmF $^{-}$(as $\mathrm{NaF}$ ) were stable towards ethanol at $85-90 \%$ compared with the control and buffalo's samples. This may be attributed to the higher effect of ionic strength given by $\mathrm{F}$ and $\mathrm{Na}^{+}$for cow's milk than that of buffalo's milk. Chavez et al. (2004) observed that the relation between ionic strength and casein was more important to alcohol stability than to coagulation stability. Horne and Parker (1981) proposed a mechanism for ethanolinduced precipitation in which the dielectric strength of the micelles medium plays an important role. While, Mohammad (1989) concluded that the low ethanol stability of buffalo milk as compared with bovine milk, may be attributed to both the higher $\mathrm{Ca}^{++}$ concentration in buffalo milk and the different proportion of the individual caseins present in both types of milk.

The sensitivity of fluoridated milk samples to $\mathrm{Ca}^{++}$is shown in Table (4). Added NaF (5-20 ppm Fo) had no effect toward sensitivity to $\mathrm{Ca}^{++}$for cow's milk. Buffalo's skim milk samples containing 10$20 \mathrm{ppm}$ F were more stable toward 5 and $7.5 \mathrm{mM} / \mathrm{L} \mathrm{Ca}^{++}$compared with control samples. Changes in the physicochemical properties of casein micelles were deduced by comparing their zeta potential values in the absence and presence of cations and the net negative charge on casein micelles decreases with increasing calcium content (Philippe et al., 2005).

It was found that all milk samples were heat stable at $125^{\circ} \mathrm{C}$ for $30 \mathrm{~min}$ irrespective of the type of milk and any concentration of $\mathrm{F}$. No problems of heat stability would be involved in the use of fluoridized milk as mentioned by several workers (Davis, 1975a,b, Beddows and Blake, 1974, 1982 and Wheeler et al., 1988a).

\subsection{Rennet coagulation properties}

Effect of $\mathrm{NaF}$ treatments on the rennet coagulation properties of milk samples is shown in (Table 5). The rennet clotting time (RCT) of the control buffalo's skim milk was shorter than that of cow's skim milk. This phenomenon probably is due to the higher calcium content, low level K-casein and larger size of casein micelles in the former than the latter (Ibrahim et al., 1973 and Amer et al., 1981). Adding (5-20 p.p.m. $\mathrm{F}^{-}$as $\left.\mathrm{NaF}\right)$ significantly $(\mathrm{P} \leq 0.05)$ increased the RCT of buffalo's and cow's skim milk compared to the control samples. At $20 \mathrm{ppm}$ F changes rate of the RCT were 69.72 and $41.3 \%$ in the buffalo's and cow's milk samples respectively. The findings could be explained by association of $\mathrm{NaF}$ to form $\mathrm{NaF} \leftrightarrow \mathrm{Na}^{+}+\mathrm{F}$ and $\mathrm{Na}^{+}$may cationic exchange taking place between $\mathrm{Na}^{+}$and $\mathrm{Ca}^{++}$leading to form sodium calcium paracesinate which is more hydrophilic and requires longer time for clotting than calcium paracaseinate. Folourine tightly bound reversible ionic complex which larger casein micelles in buffalo's milk than small casein micelles in cow's milk.

Results in Table (5) show that adding $\mathrm{NaF}$ (10-20 p.p.m. F) leads to significantly increase $(\mathrm{P} \leq 0.05)$ the firmness of buffalo's skim milk samples, but the firmness of cow's skim milk was not affected with adding $\mathrm{NaF}$.

Data given in Table (5) show that the control cow's skim milk had higher synersis (whey volume expressed as a function of the incubation time of the cut curd) than that of buffalo's skim milk. This is attributed to the lower total solid of cow's milk than buffalo's milk and differences in structure composition of casein micelles in both milk (Abd El-Salam et al., 1978 and Hofi et al., 1978). Calvo and Balcones (2000) indicated that the differences in drainage rate amount curds made from bovine, ovine and caprine milk could have been due to a different formation of the reticulum of casein micelles of casein and the salt composition can influence the coagulum structure. While, Renault et al. (1997) found that 
Table (2): Influence of added NaF (5-20 ppm Fon on the optical properties of buffalo's and cow's skim milk .

\begin{tabular}{|c|c|c|c|c|c|c|}
\hline \multirow{2}{*}{ Fo as NaF (p.p.m.) } & \multicolumn{3}{|c|}{ Optical density at 280 nm } & \multicolumn{3}{c|}{ Optical density at 260 nm } \\
\cline { 2 - 7 } & BSM & CSM & Mean & BSM & CSM & Mean \\
\hline Control & 0.405 & 0.460 & $0.433^{\mathrm{d}}$ & $0.344^{\mathrm{F}}$ & $0.381^{\mathrm{C}}$ & $0.361^{\mathrm{c}}$ \\
\hline 5 & 0.464 & 0.563 & $0.513^{\mathrm{c}}$ & $0.360^{\mathrm{E}}$ & $0.410^{\mathrm{B}}$ & $0.385^{\mathrm{b}}$ \\
\hline 10 & 0.480 & 0.575 & $0.527^{\mathrm{b}}$ & $0.368^{\mathrm{D}}$ & $0.430^{\mathrm{A}}$ & $0.399^{\mathrm{a}}$ \\
\hline 15 & 0.479 & 0.575 & $0.526^{\mathrm{b}}$ & $0.366^{\mathrm{DE}}$ & $0.434^{\mathrm{A}}$ & $0.399^{\mathrm{a}}$ \\
\hline 20 & 0.490 & 0.599 & $0.545^{\mathrm{a}}$ & $0.370^{\mathrm{D}}$ & $0.435^{\mathrm{A}}$ & $0.402^{\mathrm{a}}$ \\
\hline Mean & 0.464 & 0.554 & & $0.361^{\mathrm{b}}$ & $0.418^{\mathrm{a}}$ & \\
\hline S.E & 0.0103 & 0.0162 & & 0.0035 & 0.0068 & \\
\hline
\end{tabular}

BSM= Buffaloe's skim milk

CSM= Cow's skim milk.

Different superscripts $(\mathrm{A}, \mathrm{B}, \mathrm{C}, \mathrm{a}, \mathrm{b}, \mathrm{c}, \ldots)$ at the same column are significantly different $(\mathrm{P} \leq 0.05)$.

S.E $=$ Standard Error

Table (3): Influence of added NaF (5-20 ppm Fo) on ethanol stability of buffalo's and cow's skim milk.

\begin{tabular}{|c|c|c|c|c|c|c|c|c|c|}
\hline \multirow{2}{*}{$\begin{array}{c}\text { Fó as NaF } \\
\text { (p.p.m) }\end{array}$} & \multicolumn{8}{|c|}{ Alcohol concentration \% } \\
\cline { 2 - 9 } & 95 & 90 & 85 & 80 & 95 & 90 & 85 & 80 \\
\hline Control & + & + & + & - & + & + & + & - \\
\hline 5 & + & + & + & - & + & + & + & - \\
\hline 10 & + & + & + & - & + & + & + & - \\
\hline 15 & + & + & + & - & + & + & + & - \\
\hline $2 n$
\end{tabular}

Table (4): Influence of added $\mathrm{NaF}\left(5-20 \mathrm{ppm} \mathrm{F}\right.$ ) on the sensitivity to $\mathrm{Ca}^{++}$of buffalo's and cow's skim milk.

\begin{tabular}{|c|c|c|c|c|}
\hline \multirow[t]{2}{*}{ F́ as NaF (p.p.m.) } & \multirow{2}{*}{$\begin{array}{c}\text { Species of skim } \\
\text { milk }\end{array}$} & \multicolumn{3}{|c|}{$\mathrm{Ca}^{++}$concentration } \\
\hline & & $5 \mathrm{mM} / \mathrm{L}$ & $7.5 \mathrm{mM} / \mathrm{L}$ & $10 \mathrm{mM} / \mathrm{L}$ \\
\hline \multirow{2}{*}{ Control } & BSM & + & +++ & +++ \\
\hline & CSM & - & - & - \\
\hline \multirow{2}{*}{5} & BSM & + & +++ & +++ \\
\hline & CSM & - & - & - \\
\hline \multirow{2}{*}{10} & BSM & - & ++ & +++ \\
\hline & CSM & & & \\
\hline \multirow{2}{*}{15} & BSM & - & + & +++ \\
\hline & CSM & - & - & - \\
\hline \multirow{2}{*}{20} & BSM & - & + & +++ \\
\hline & CSM & - & - & - \\
\hline
\end{tabular}

BSM= Buffaloe's skim milk

CSM= Cow's skim milk.

$-=$ Non clotting $+=$ Fair clotting

$++=$ Medium clotting. $+++=$ Strong clotting. 
Table (5): Influence of added NaF (5-20 p.p.m. F ) on the clotting rennet properties of buffalo's and cow's skim.

\begin{tabular}{|c|c|c|c|c|c|c|c|c|c|}
\hline \multirow{2}{*}{$\begin{array}{c}\text { Fo as NaF } \\
\text { (p.p.m) }\end{array}$} & \multicolumn{3}{|c|}{ Rennet clotting time (min.) } & \multicolumn{3}{|c|}{ Firmness (N) } & \multicolumn{3}{|c|}{$\begin{array}{l}\text { Volume of whey (ml) expressed from } 100 \mathrm{~m} \\
\text { of cut curd in } 60 \mathrm{~min} \text {. }\end{array}$} \\
\hline & BSM & CSM & Mean & $\begin{array}{l}\text { BSM } \\
\end{array}$ & CSM & Mean & BSM & CSM & Mean \\
\hline Control & $1.225^{\mathrm{G}}$ & $2.420^{\mathrm{C}}$ & $1.822^{\mathrm{c}}$ & $0.185^{\mathrm{C}}$ & $0.155^{\mathrm{C}}$ & $0.170^{\mathrm{b}}$ & $3.950^{\mathrm{H}}$ & $39.000^{\mathrm{E}}$ & $21.475^{\mathrm{e}}$ \\
\hline 5 & $2.295^{\mathrm{D}}$ & $3.305^{\mathrm{B}}$ & $2.800^{\mathrm{a}}$ & $0.190^{\mathrm{C}}$ & $0.155^{\mathrm{C}}$ & $0.173^{b}$ & $4.300^{\mathrm{H}}$ & $63.000^{\mathrm{A}}$ & $33.650^{\mathrm{cd}}$ \\
\hline 10 & $2.150^{\mathrm{EF}}$ & $3.325^{\mathrm{B}}$ & $2.738^{\mathrm{b}}$ & $0.240^{\mathrm{B}}$ & $0.155^{\mathrm{C}}$ & $0.198^{\mathrm{ab}}$ & $4.300^{\mathrm{H}}$ & $59.000^{\mathrm{B}}$ & $31.650^{\mathrm{d}}$ \\
\hline 15 & $2.195^{\mathrm{E}}$ & $3.375^{\mathrm{B}}$ & $2.785^{\mathrm{ab}}$ & $0.240^{\mathrm{B}}$ & $0.155^{\mathrm{C}}$ & $0.198^{\mathrm{ab}}$ & $35.000^{\mathrm{EF}}$ & $57.000^{B}$ & $46.000^{\mathrm{b}}$ \\
\hline 20 & $2.080^{\mathrm{F}}$ & $3.485^{\mathrm{A}}$ & $2.783^{\mathrm{ab}}$ & $0.310^{\mathrm{A}}$ & $0.155^{\mathrm{C}}$ & $0.233^{\mathrm{a}}$ & $49.000^{\mathrm{C}}$ & $55.000^{\mathrm{B}}$ & $52.000^{\mathrm{a}}$ \\
\hline Mean & $1.989^{\mathrm{b}}$ & $3.182^{\mathrm{a}}$ & & $0.234^{\mathrm{a}}$ & $0.155^{\mathrm{b}}$ & & $19.310^{\mathrm{C}}$ & $54.60^{\mathrm{a}}$ & \\
\hline S.E & 0.1297 & 0.1289 & & 0.0171 & 0.0017 & & 6.3530 & 2.7976 & \\
\hline
\end{tabular}

BSM= Buffalo's skim milk

$\mathrm{CSM}=$ Cow's skim milk

$\mathrm{N}=$ Newton.

Different superscripts $(A, B, C, a, b, c, \ldots)$ at the same column are significantly different $(\mathrm{P} \leq 0.05)$.

S.E $=$ Standard Error. 
synersis could be influenced by changes in the protein conformation essentially due to hydrophobic bounding.

Buffalo's and cow's skim milk contained 20 and 5 ppm $\mathrm{F}^{\circ}$ (as $\mathrm{NaF}$ ) respectively had the highest significantly increased synersis compared with other treatments. The pattern of synersis rate was significantly different $(\mathrm{P} \leq 0.05)$ among the buffaloe's and cow's milk. The alteration of synersis by adding $\mathrm{NaF}$ may be due to the different modification in the distribution of calcium between aqueous and colloidial phases and rearrangement of the protein network occurring after adding $\mathrm{NaF}$. The intensity of these changes depends on the mature casein and concentration of $\mathrm{NaF}$. Previous studies showed that addition of up to $300 \mathrm{mM} / \mathrm{L} \mathrm{NaCl}$ did not affect the volume of whey expressed from the curd, but at $500 \mathrm{mM} / / \mathrm{L}$ there was slight increase in the synersis (Grufferty and Fox, 1985).

It appears that the key-mechanism through which added $\mathrm{NaF}$ induces modification in the physico-chemical properties of milk .

\section{REFERENCES}

Abd El-Salam M.H., Osman Y.M. and Nagmoush M.R. (1978). Comparative study of composition of casein micelles from buffalo's and cow's milk. Egyptain J. Dairy Sci., 6:1-8.

Al-Khateeb T.L., Al-Marasafi A.I. Bastawi A.A. and Darwish S.K. (1991). Report on: Prevention of dental caries through fluoridation of drink water in Saudi Arab King Abdul Aziz University. P:1-110

American Academy of Pediatrics (1979). Public health: Facts: Fluoride drinking water, 63:150-152.

American Academy of Pediatries (1986). Committee on nutrition; fluoride supplementation. 77: KE 6069-6071.

Amer S.N., Abdel-Hamid L.B. and Zedan A.N. (1981). Rennet coagulation time of goat's, sheep's, buffalo's and cow's milk 1. Effect of dilution and heat treatment. Egyptian J. Dairy Sci.,1:19.

Banoczy J. (1997). Milk fluoridation: an alternative method for caries prevention. Fluoride 30:116-117.
Beddows C.G. (1982). The status of fluoride in bovine milk. I. Fluoride in cold milk. J. Food Technology. 17:55-62.

Beddows C.G. and Blake, C. (1974). An investigation of the effect of pasteurization on milk containing fluoride. J. International Congress of Food Sci. and Technolgy. 19:12-13.

Beddows C.G. and Blake C. (1982). The status of fluoride in bovine milk. II. The effect of various heat treatment processes. J. Food Technology. 17:6370.

Berridge N.J. (1952). Some observation on the determination of the activity of rennet. Analyst. 77:57-62.

Bian J.Y., Li R.Y. and Wang W.J. (1995). Feasibility of milk fluoridation and trends in dental caries of children in China. Adv. Dent. Res. 9:112.

Bian J.Y., Wang W.H., Wang. W.J., Romg W.S.and Lo C. (2004). Effect of fluoridated milk on caries in primary teeth: 21-mouth results. J. EvidenceBased Dental practice. 3:241-245.

Calvo M.M., and Balcones E. (2000). Some factors influencing the synersis of bovine, ovine and caprine milk. J. Dairy Sci., 83:1733-1739

Chavez M.S., Negri L.M., Taverna M.A. and Cuatrn A. (2004). Bovine milk composition parameters affecting the ethanol stability. J.Dairy Res. 71:201206.

Davis J.G. (1975a). Fluoridised milk for children-Part I. Dairy Industries J. 40:7-10.

Davis J.G. (1975b). Fluoridised milk for children-Part II. Dairy Industries J. 40:48-51.

Davis J.D. (1979). Fluoridised milk as an alternative to water fluoridation. Milchwissenschaft. 34:721-725.

El-Gabry E.K., and Darwish S.S. (2003). Effect of fluoride content of diet on dental and periodontal diseases. Egypt. J. Food Sci., 31:259-270.

El-Shabrawy S.A., and Haggag A.F. (1980). Studies on the electrical conductivity of milk. Egyptian J. Dairy Sci., 8:95102.

El-Shibiny S., and Abd El-Salam. M.H. (1973). Studies on the electrical conductivity of buffalo's and cow milk. Milchwissenschaft. 28:571-575. 
Garrec T.P., and Plebin R. (1986). The concentration of fluorine in different dairy products made from contaminated milk. Sci. Total environ, 50:183-190.

Grufferty M.B., and Fox P.F. (1985). Effect of added $\mathrm{NaCl}$ on some physicochemical properties of milk. Ir. J. FDSI, Technol. 9:1-9.

Hofi A.A., Mahran G.A., Abd El-Hamid L.B., Hagrass A.E.A. and Hammad Y.A.(1978). Some factors on the curd tension of buffalo's milk. Egyptian J. Dairy Sci.,6:135-142.

Horne D.S., and Parker T.G. (1980). The pH sensitivity of the ethanol stability of individual cow milk. Neth. Milk Dairy. 34:126-130.

Horne D.S., and Parker T.G. (1981). Factors affecting the ethanol stability of bovine milk II. The origin of the $\mathrm{pH}$ transition. J. Dairy Res. 48:285-291.

Ibrahim M.K., El-Abd M.M. and Amer S.N. (1973). A study on calcium caseinate phosphate particles of buffalo milk. Egyptian J. Dairy Sci.,1:7-12.

Junkkarinen L., and Kreula M. (1976). On the metabolism of fluoride by cows on protein- free and normal feed. Mejjerililellinen Aikakausk irja. Cited from D.S.A. 1977:1127.

Levy S.M., Kohout F.J., Guha-Chowdhury N., Kiristy M.C., Heilman J.R. and Wefel J.S. (1995). Infants fluoride from drinking water alone and from water added to formula beverages and food. J. Dent. Res. 74:1399-1402.

Mabrook M.F., and Petty M.C. (2003). Effect of composition on the electrical conductance of milk. J. of Food Engineering 60:321-325.

Marino R. (1995). Should we use milk fluoridation? A review. Bull Pan Am Health organ. 29:287-298.

Marshall R.J. (1982). An improved method for measurement of the synersis of curd formed by rennet action on milk. J. Dairy Res. 49:329-336.

Mohammad K.S. (1989). Ethanol induced coagulation of buffalo milk. Egyptian J. Dairy Sci.,17:239-246.

Nakai S., and Le A.C. (1970). Spectrophotometeric determination of protein and fat in milk simultaneously. J. Dairy Sci., 53:276-279.
Natailianas H.A., and Whiteny M.C.J. (1964). Calcium as an indicator for the determination of total calcium and magnesium and calcium alone in the same aliquot of milk. J. Dairy Sci., 47:19-26.

Philippe M., Le Graet Y. and Gaucheron F. (2005). The effect of different cations on the physicochemical characteristics of casein micelles. Food Chemistry. 90:673-683.

Renault C.E., Gastaldi E., Lagaud A., Cup J.L. and Tarsds de la Fuenle B. (1997). Mechanisms of synersis in rennet and without mechanical treatment. J. Food Sci. 62:907-911.

Rugg-Gunn A.J. (1993). Nutrition, diet and dental public health. Community Health Suppl. 2:47-56.

SAS User's Guide Statistical Version 8.0 (2000). SAS Institute Inc., Cary, NC, U.S.A.

Sharma V., and Sindhu J.S. (2001). Physical properties of milk as influenced by the alteration in ionic calcium and magnesium. Indian J. Dairy Sci.,54:19-22.

Shehata A., Ibrahim J.A. and Shabaan A.A. (1985). Effect of industrial pollution on mineral content of cow's and buffaloe's milk. Fluorine, Calcium and Phosphorus. Assiut Veterinary medical J. 13:223-228.

Standard method for examination of water and wastewater (1989)"Spadns method". Amercian public health association. Washington, DC. U.S.A. P359-362.

Tamime A. Y., Kalab M. and Davis G. (1989). Rheology and microstructure of strained yoghurt (Labneh) made from cow's milk by three different methods. Food Microstructure 8:125132.

Therthai N., and Zhou W. (2001). Artificial meural network modeling of the electrical conductivity property of recombined milk. J. of Food Engineering. 50:107-111.

Villa A.E., Guerrero S.,Cisternas P. and Monckeberg K. (1989). Fluoride bioavailability from disodium monofluorophosphate fluoridaled milk in children and. Rats. Caries Res. 23:179-183. 
Villa A.E., Guerrero S., Icaze G., Villalolos J. and Anabalon M. (1998). Dental fluorosis in Chilean children: Evaluation of risk factors. Community Dent Oral Epidemiol. 26:16-25.

Wheeler S.M.L., Mckay B. and Nguyen M.H. (1988a). The effect of evaporation and spray-drying upon total and ionic fluoride concentration in milk. The Australin J. Dairy Technology 43:1-5.
Wheeler S.M.L., Turner A.D. and Macfarlance J. (1988b). Comparison of four method used to measure total fluoride and one method for ionic fluoride in bovine milk, using the fluoride ion-selected electrode. The Australin J. Dairy Technology. 43:21-26.

Wieczorek P., Sumujlo D., Chlubek D. and Machoy Z. (1992). Interaction of fluoride ions with milk proteins by gel filtration. Fluoride 25:171-174.

$$
\begin{aligned}
& \text { تأثير إضافة الفلوريد للبن الفرز الجاموسى والبقرى } \\
& \text { أولا: على بعض الصفات الطبيعية والكيميائية } \\
& \text { إسماعيل حسين إسماعيل عبد الغنى } \\
& \text { قسم علوم وتكنولوجيا الألبان ـ كلية الزراعة ـ جامعة القاهرة ـ الجيزة ـ مصر }
\end{aligned}
$$

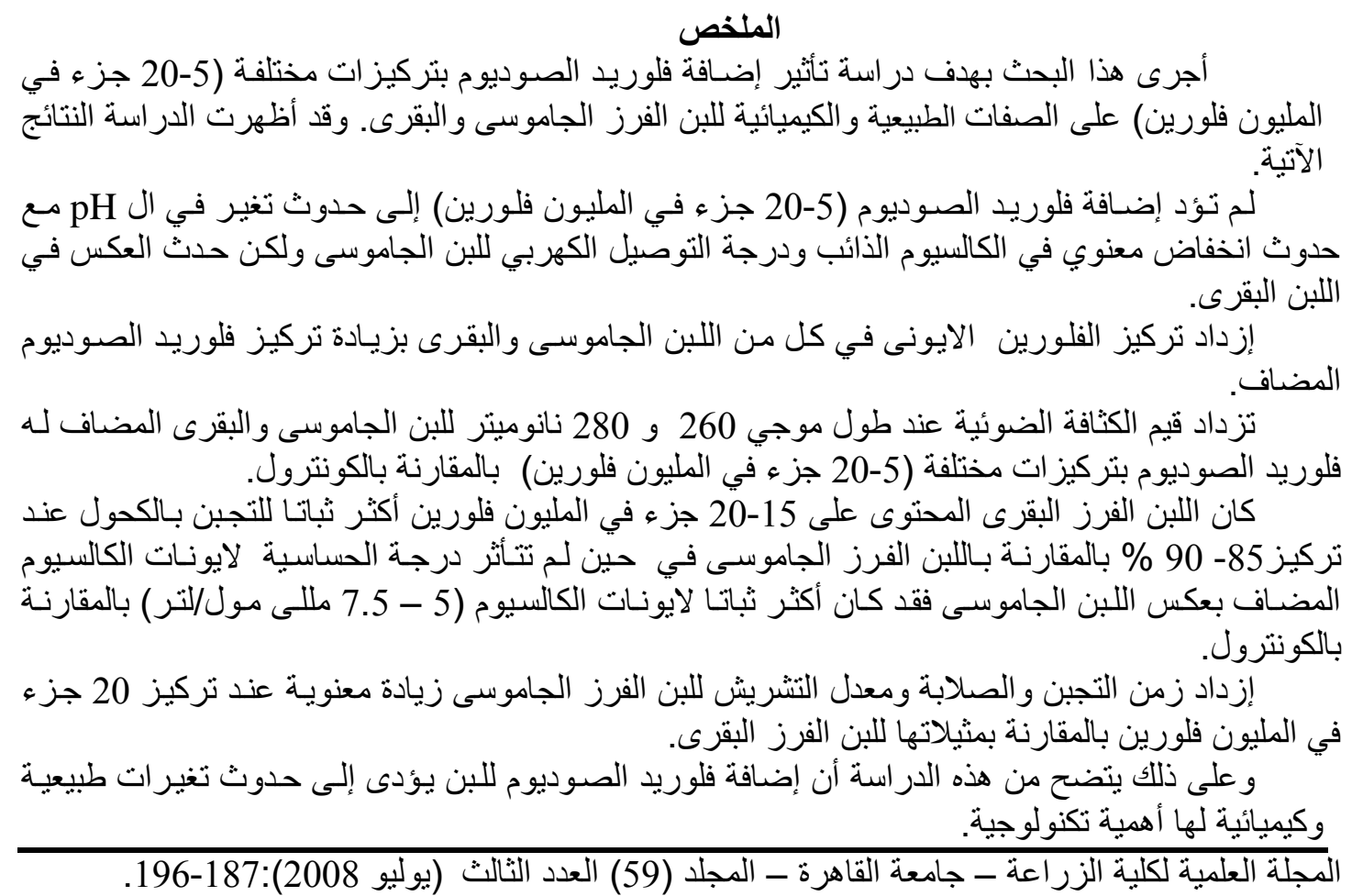

